\title{
Between Abuja and Lagos: Insights of Price and Value in Residential Real Estate
}

Ndubisi Onwuanyi ${ }^{1}$

${ }^{1}$ Department of Estate Management, Faculty of Environmental Sciences, University of Benin

To cite this article: Onwuanyi, N. (2018). Between Abuja and Lagos: Insights of Price and Value in Residential Real Estate. Journal of African Real Estate Research, 3(2), pp.107-129. DOI: $10.15641 /$ jarer.v3i2.559.

\begin{abstract}
Nigeria's most prominent real estate markets are Lagos and Abuja. Between the years 2011 to 2015 saw unusually steep prices and pronounced vacancies in Abuja's high-end residential segment compared to Lagos'. This discrepancy suggests market differences which are deserving of investigation. This paper, therefore, comparatively examines these two markets by exploring the economic concepts of price and value which sustain the market system. The data was sourced by a questionnaire administered to estate surveyors and valuers as well as the asking prices from property archives. The main finding of this paper is that Abuja's prices and rents significantly exceed Lagos' despite it being a less economically productive city. One can conclude that the Lagos market is more resilient while Abuja's buoyancy is more apparent than real.
\end{abstract}

Keywords: Price; Value; Real Estate Markets; Abuja; Lagos

\section{Introduction}

The most prominent real estate markets of Nigeria are to be found in the cities of Abuja and Lagos. These urban locations offer investment opportunities mainly in commercial, residential and industrial property. Due to the basic need for shelter and overpopulation, there is a substantial housing shortfall in both locations - Lagos is 2.5 million units short (Lagos Bureau of Statistics, 2015) and 600,000 for Abuja (RIRFHUD, 2017). Thus, residential development is the most favoured investment outlet. The evident demand for housing in Nigeria's expanding economy under conditions of rapid urbanisation in both cities implies that the bulk of production will end up either in the investment or letting sub-sectors of the real estate market, as developers characteristically pursue the profit motive.

\footnotetext{
${ }^{1}$ Email: ndubisi.onwuanyi@uniben.edu

Tel: +2348033159430
} 
The marketplace, as the forum of interaction for makers and takers, determines and delivers the rewards of real estate production. This outcome is achieved after price is taken into account. The market rewards appropriately through the instrumentality of the price mechanism, the defining feature of the free market economy (Brems, 1991). Being part of a market economy, Nigeria's real estate market is governed by price. Thus, where there is a marketplace challenge in respect of real estate outputs, questions arise regarding the basis of investment decisions. Such situations underscore the necessity for investor-producers to possess market knowledge as well as seek investment advice. For Nigeria's producers of "to-let" and "for sale" real estate, this is especially important since the relatively lengthy production period and the immobility of the finished product accentuates the risk of vacancies and unsold property. This is particularly true if market conditions change or investment expectations are unrealistic from the start, thereby bringing complications of uncertainty and risk to the development process (Darlow, 1982). Since profit and loss are ultimately determined in the marketplace, knowledge of the market (its situation, characteristics, trends and prospects) is essential for successful investing. Regarding real estate production, successful investing can be seen to have taken place if "to let" and "for sale" outputs are disposed of not only within a reasonable time after completion but also, within rent and price expectations. Failure in this regard creates the troubling situation of long-lasting vacancies and unsold development.

In these most prominent real estate markets of Nigeria, significant differences were observed in terms of price, vacancies and unsold development in the high-end residential sector between 2011-2015. It was observed that Abuja prices for development land and completed development were consistently and vastly higher at the same time. Furthermore, its market had a higher level of unlet and unsold development. This research effort intends to resolve whether or not the price differences are unusually high for Abuja relative to Lagos. Furthermore, it assesses if this trend is truly indicative of market buoyancy considering Abuja's high level of vacancies and unsold development.

Since markets and economic activity are the subjects of this study, the economic concepts of price and value are of relevance to the evaluation. There is, therefore, an exploration of these concepts upon which the market system is built and sustained. The aim is to evaluate the extent to which price and value as economic principles help to explain prices in the study areas, especially the vacancy phenomenon. Price plays a vital role in this investigation because it leads to value. Value is important because it emanates from market prices. As such, prices must have a basis in value. And value, in respect to the real estate good, must symbolise potential and actual productivity, affordability, availability and utility. Together these aspects bring value-seeking buyers to the marketplace.

For at least three possible reasons, vacancy, as a phenomenon, is not alien even to thriving property markets. First, it is unusual and virtually impossible for all property to be taken up at any point in time under normal market conditions. Furthermore, production is continuous where demand is strong because potential profitability is always an incentive for developers. Lastly, 
the heterogeneous nature of real estate and the reality of human differences in taste means that some property may not always meet buyer or user requirements. However, the existence of pronounced vacancies under a regime of high prices which should ordinarily indicate a resilient market is suggestive of an anomaly. Thus, the study involves comparisons and contrasts which arise from two angles. Firstly, it compares Abuja and Lagos' asking prices for the five-year period. Secondly, it contrasts the economic concepts of price and value and argues that not only do price and value differ, but so do the markets of Abuja and Lagos.

The topic is relevant to existing and prospective investors in the high-end residential segment in the study areas, particularly Abuja. It highlights the necessity of having a better understanding of the market and the importance of professional real estate advice. It is believed that these aspects will make for better decision-making. Similarly, the topic calls the attention of policymakers to the importance of supporting the real estate industry through legislative reform of land administration and other measures of enablement and enhancement for improved performance. This research is a pioneering comparative study of these two leading real estate markets as well as of the Abuja vacancy phenomenon. Comparable upscale residential districts were identified in each city as study areas, and the price range for land and buildings was obtained from records of Nigeria's real estate marketing publication Castlesweekly. In addition, field data was gathered from estate surveying and valuation firms. The instrument of data gathering was a questionnaire on market issues and other relevant topics in the two locations. The questionnaire was administered to respondent firms. The questions were designed to allow the respondents to rank the variables according to their order of significance. The results were analysed and presented using the Relative Importance Index method.

The findings suggest that Abuja's prices were consistently higher than Lagos'. This trend was adjudged by respondents to be not only unjustified in terms of comparative economic performance, but also, anomalous since it was accompanied by high vacancies and developments which had remained unsold for periods exceeding one year. There are also characteristic differences between the two locations; exceeding terms of land supply, land accessibility and vacancy levels, which confirms that real estate markets tend to differ according to local conditions.

Following the introduction, the paper defines its scope, undertakes a literature review; rationalises the study by identifying the gap which it aims to fill. It then outlines the methodology and subsequently reports and analyses the survey results. It discusses the findings and identifies practical implications before reaching a conclusion and making recommendations.

\section{Scope of The Study}

This paper studies high-end residential price differentials between Abuja and Lagos and attempts to explain the pronounced phenomenon of vacancy over the review period with the intention of understanding these markets better. For comparison with asking prices, it would have been useful to have data on completed transactions, but this was not possible in any significant quantity 
in the absence of a public data bank. Nonetheless, since this study is more about price than about value - how price leads to value - it is appropriate to make use of asking prices. It was, after all, the high published asking prices of Asokoro and Maitama in Abuja that gave rise to the investigation. Asking prices for this work were collated from property market publications. In the absence of a comprehensive market database, the vacancy phenomenon had to be examined by seeking the market knowledge and perceptions of experienced practitioner firms in these markets. The target population, therefore, constitutes of estate surveying and valuation firms. They are chosen as being the group most relevant to the investigation because, by training and function, they possess knowledge and experience of market characteristics, trends and prospects.

\section{Literature Review}

Real estate investment is a rational economic activity. The objective of all economic activity is to obtain value. This is achieved by creating usefulness which enables the delivery of value in exchange. The norm is for value to be delivered to the consumer in the form of the satisfaction of his want, and the producer in terms of compensation. This human desire to obtain value leads Harvey (1996) to assert that modern economies are often referred to as 'exchange economies' in which people produce not merely for the satisfaction of their wants, but in order to trade or exchange their extra output. Real estate or property investment (investment in land and improvement of land) is also an economic activity aimed at obtaining value. Real estate development is the outcome of a process of production which requires costly inputs in order to achieve a profitable outcome. It is a process aptly described by Fraser (1984: p.237) as "the advancement of the usefulness of land".

Real estate, real estate markets and the real estate industry are vital to the modern economy. The World Bank (1989: p.87) acknowledges the role of real estate, stating that "in most countries, real estate (including land) accounts for between half and three-quarters of national wealth". This statement implies that it is impossible for countries to create wealth without real estate, or to be wealthy without possessing it. According to Minguzzi (2014), real estate helps to boost the modern economy in the following four ways. Firstly, it enables economic activity through the production and supply of space for industry and business. Secondly, real estate secures employment provision for professionals, artisans and other workers. Thirdly, it complements and supports the government's infrastructure policy through real estate development. Lastly, real estate provides an investment outlet through which institutional investors can maximise returns on investible funds. These roles also highlight the importance of governments in enabling, protecting and enhancing real estate markets.

The real estate markets of Abuja and Lagos are essential to Nigeria's economic development, especially as these are leading centres for foreign real estate investment. For instance, Nigeria's economy was on a growth trajectory in 2011-2015 with the World Bank (2017) reporting an average growth rate of 5.7\% per annum between 2006 and 2016. Specifically, between 20112015, GDP grew at the average rate of $4.8 \%$ per annum according to Nigeria's Economic Recovery and Growth Plan (2017). The National Bureau of 
Statistics (2016) further reports that real estate was part of this growth with a GDP contribution of $7.53 \%$ and $7.5 \%$ in 2011 and 2015 respectively. According to PwC (2015), investment in the real estate sector was $\$ 9.16$ billion in 2014 and was projected to increase to $\$ 11.36$ billion in 2015 . The industry is projected to achieve an annual growth rate of $9.49 \%$ between 2016 and 2020 (Akande, 2017). Given these prospects, investors, both prospective as well as existing, would benefit from gaining a better understanding of these local economies and real estate markets.

The history of property markets in Nigeria is comparatively more recent than those of western systems for two fundamental reasons. Firstly, the international real estate market is founded upon the concept of private property rights and the transferability of such rights. However, in the space now known as Nigeria, Mabogunje (2009) explains that pre-colonial traditional systems permitted communal land ownership only. Second, as a consequence, land was never alienated. He further reiterates this upon stating that "To sell land to a stranger or migrant was to render the security of the community concerned a hostage to fortune. Hence, when the colonialist came, everywhere he went he was told that there was no tradition of alienating land" Mabogunje (2009: p.4). However, with British interventionism, the established customary order was subjected to change as the colonialist sought land for their activities. Real estate markets have since developed in Nigeria with the cities of Lagos, Abuja and Port Harcourt being the most important centres.

The very fact that these Nigerian cities differ as to location and function suggests that differences would exist between them concerning their economies, which in turn, should be reflected in the strengths and characteristics of their real estate markets. Lagos and Abuja, the subjects of this paper, have some similarities and differences. The similarities are that Abuja is federal capital while Lagos once was, and both cities have thriving real estate markets. Furthermore, both locations have a substantial shortfall in residential accommodation, rapid urbanisation and annual per capita incomes which are significantly higher than the $\$ 2,450$ national average; with Lagos at $\$ 4,333$ and Abuja's lower at $\$ 2,685$ (World Bank, 2015). The contrasts are that Lagos is an industrial and business city while Abuja's function is administrative. Lagos is coastal and Abuja inland. Lagos is an old city while Abuja is relatively new meaning that Abuja had the benefit of a master plan from scratch which Lagos did not. Furthermore, Abuja was created in postindependence Nigeria while Lagos came into prominence under colonialism; and finally, Lagos' population is seven times that of Abuja.

The logical reasons why local market differences should exist between both locations are that physical real estate, rights in which are traded in these markets, is fixed in location as well as being a factor input necessary for economic production. Thus, the level of local productivity determines the value which prospective and existing investors ascribe to real estate. Potential and actual productivity, as well as affordability are prime considerations for people in making their value assessments. Fraser (1984) reiterates this point upon stating that people rationalise the payment of rent by confirming through calculations the potential profitability of a location and are thus able to make bids on a competitive basis. The same logic applies to the buying of real 
estate. Where local conditions do not result in effective demand for particular types of real estate, the consequences come as a drop in its value and unlet or unsold property.

As with other economic activities, real estate investment is guided by the economic principles of price and value, both of which are rationally founded. While it is acknowledged that sellers may set prices arbitrarily, real estate market trends guide prospective sellers in rationalising their expectations in tune with reality. As such, new investment in real estate development would be rationalised by the prospects offered by the level of returns to existing investors. Price expectations on new investments should have a basis in market trends and prospects, both of which reflect market strength. A situation in which sellers' expectations vary significantly from buyers naturally should raise questions as to whether the figures mentioned are arbitrary price expectations or realistic price expectations founded upon market performance. If such discordantly high figures are described as prices, then they may not necessarily represent value. If, then, they are not values, then they are not reflective of the true strength of the market; if the prices are not reflective of the market, then they give a false notion of the real estate industry which, as has been asserted, reflects the productivity and prospects of the local economy. As clarified by Blackledge (2009: p.27) "In the end, value comes down to what a prospective purchaser or tenant is ready and able to pay and what the prospective vendor or landlord is financially able and willing to accept. Unless a figure satisfactory to both can be achieved, all valuation theory is pointless. There is no use in deciding that a property is worth a certain value if nobody is prepared and able to purchase or rent it at that price".

Thus, the two parties to a property transaction are essentially engaged in a search for value. It is a search which is built on expectations. The seller positions himself to receive value by seeking a price which meets his expectation but may yet accept a lower price based on the expectations of the buyer. The buyer approaches his idea of value by agreeing only to a price which makes it possible to attain his investment motive(s). If, then, both price and value have "expectations" as a denominator, can it be claimed that price and value are one and the same? The indications are that they are not. In terms of price, "expectations" relate to recompense while in the case of value they pertain to utility. Furthermore, Olajide et al. (2016: p.4) make the distinction that: "price is what you pay for goods or services you receive...value is what goods or services pay you". Price and value are emphasized as there is a need to address the extent to which these concepts should apply to real estate development which have been undesired for lengthy periods of one year and more, yield no income and meet no needs, but bear high price tags and continuously remain in the market, either to let or sold.

The observed high prices of Abuja may not have been indicative of high value as speculations by the general public trailed them, while doubts of their validity were expressed by real estate brokers (Etteng, 2015; Adejokun \& Yunusa, 2015). Three reasons may account for this speculation and doubt. First, Abuja prices and rents are consistently and vastly higher than for comparable locations and similar facilities in Lagos; an older market with a proven resilience. Another reason is that the figures appear unrealistic and out 
of tune with the basic administrative function of Abuja. Again, it defies rationality for developed property to be left vacant for upwards of eight years when there are people who have a need for it (Kolawole, 2015).

It is important to establish whether or not these prices are indicative of value. If indeed such prices are indicative of value, then being reflective of the productivity of the Abuja economy, they should impact positively upon the volumes of real estate sales and lettings. Fraser (1984) observes property values and macroeconomic trends are inter-reliant. However, the phenomenon of unusual vacancies in Abuja would tend to contradict the view that its higher prices reflect higher values as well as economic productivity, relative to Lagos.

Vacancies exist in both of these markets. But in 2011-2015 they were more pronounced in Abuja at a time when its prices were far higher than Lagos'. Residential or household vacancies exist when completed property available for occupation is either unoccupied or unsold for one reason or another over a length of time which may differ from country to country as the vacancy phenomenon is observable in different parts of the world (Nam et al., 2016). However, if the percentage or extent of vacancies is unusually high, they are considered to be a disadvantage. The factors responsible for vacancy may differ especially between developed and developing economies. Where incomes are low and urban growth rapid, as experienced in developing countries, vacancies are linked with an inadequacy of dwellings and affordability issues. Research on South Korea (Nam et al., 2016) finds that vacancies as symptoms of regional issues consequent upon urban development may also arise from reasons such as rapid and excessive supply, an ageing population, the growth of slums, migration or city shrinkage. These situations may lead to more houses being unoccupied. According to Economistview (2005), there is a natural vacancy rate which is not a constant and may change, either causing price rises or falls. Therefore, knowledge of this natural rate helps in giving an understanding of real estate markets.

Intrinsically, the notion of vacancy is not always a disadvantage as might be supposed, for, without it the migration of people and households from one urban location to another would be hampered. It is natural that accommodation should be available in desired locations if and when people decide, or have to move, to a new house. The existence of vacancies ensures the availability of accommodation for intra-urban and inter-urban migrants. The vacancy characteristic of Abuja is yet to be addressed by researchers. The dearth of studies on this issue suggests that an investigation would be a necessary step towards a better understanding of the factors at play. It is an integral part of this study to resolve whether or not the pronounced Abuja vacancy phenomenon is a disadvantage and to identify the factors responsible for it.

The speculations of the public and the doubts expressed by practitioners as to Abuja prices have not been reflected in published real estate research. This may well be an oversight and not because the topic is not of interest to practitioners, academics and policymakers. Indeed, the role of real estate in the economy coupled with the human need for shelter suggests that there will be economic, social and environmental implications in conditions of long- 
lasting vacancies, unsold development and significant housing deficits. In line with this, Onwuanyi et al. (2017: p.401) advance the argument that underperforming real estate investments constitute a loss not only to their owners, but also to the macroeconomy because a nation's wealth consists of "the totality of the assets of all its citizens and those of the State".

Nevertheless, published research on Abuja and Lagos' residential property during, and immediately after, the study period reveals an engagement with price and value issues from perspectives which are relevant to this study. For example, Abidoye and Chan (2016) consider the determinants of real estate investment value in the Lagos market. The authors empirically identify, for the benefit of existing and prospective investors, the variables which affect value so that they may better understand the real constituents of value. Their findings that location and neighbourhood characteristics are the two most important variables affecting value serves to confirm the assertion that real estate markets are essentially local. Odubola et al. (2017), in examining the factors which affect residential rental values in Lagos, identify income (and location to a lesser extent) as having the greatest significance. This finding is essential in explaining why a lettable property may remain on the market for lengthy periods if price and location are not right.

Regarding the Abuja market, Wahab et al. (2017) studied the relationship between property returns and macroeconomic factors. Their findings are that property returns are significantly influenced by macroeconomic indicators (the real GDP, exchange rate, inflation, interest rate and employment rate), leading them to recommend that "policymakers should painstakingly study past and present economic policies before instituting new policies because such policies could adversely affect the property market ... this could affect the contribution of the real estate sector to national economic development" (Wahab et al., 2017: p.81). This finding confirms the interrelationship of real estate markets and the economy and why it may be anomalous for high prices not to connote high values - for if values are high, then so would be the returns.

Oyetunji and Olowofeso (2016) and Oloke et al. (2017) discuss the issue of pricing in the Lagos market. Pricing is distinct from value as it relates to those factors which determine market output, or which define the expectations of producers (sellers and lessors), whereas value arises only after marketplace interactions. The former examined the effect of selected macroeconomic variables on the price of houses and flats. The study revealed a positive correlation of the interest rate and exchange rate and that residential property prices are sensitive to fluctuations in macroeconomic variables. These findings serve to reinforce the importance of the macroeconomy in real estate investment decisions. The latter study seeks to explain the residential vacancy phenomenon in the Lagos market which was trailed by "speculation as to whether the...price regime is simply a case of price mismatch, an inappropriate pricing strategy, principal-agent exuberances or a case of housing price bubble that will soon burst" (Oloke et al., 2017: p.29). This is done by a survey of stakeholders, namely property owners, property agents and property developers. The finding is that property owners' insistence on unilateral price fixing disregards the established principles on which professionals are best suited to offer advice. This, in turn, prolongs the time 
real estate listings remain on the market. This finding is of great relevance to this present study as it highlights an important characteristic of the Lagos market which needs to be compared with the Abuja situation. The finding also explains the rising rate of vacancy in the Lagos market. Again, it underscores the essentiality of market knowledge (its situation, characteristics, trends and prospects) for successful investing. These authors also elucidate the various ways in which price features in the marketplace by identifying asking (or selling) price; transaction (or traded) price, and lastly, optimal price which is attained when 'the able buyer's valuation equals the least a seller can accept" (Oloke et al., 2017: p.29). These distinctions reinforce the earlier assertion that price is a factor of the market.

The literature review, therefore, reveals the following salient issues. First, the real estate industry is important to Nigeria because of its growing contribution to GDP and economic development. Second, the economic principles of price and value form the bases of decision-making in real estate investments. Third, real estate values are market-derived and must be realistic in order to have meaning. Fourth, property values and macroeconomic trends are inter-reliant. Fifth, real estate markets are locally-based, and therefore, would tend to vary in characteristics from one location to the other. Sixth, vacancies are not unusual but constitute a disadvantage if they become excessive. Lastly, there is a dearth of comparative studies on the Abuja and Lagos real estate markets and the pronounced vacancies and unsold development in Abuja.

Against the given backdrop, this study espouses the view that the issues identified in the literature review can be elucidated by an investigation of Abuja and Lagos 2011-2015 price trends. It does so with the aim of establishing whether or not Abuja's prices were:

(a) Unusually high;

(b) Indicative of buoyancy;

(c) Suggestive of value, especially in light of the high levels of vacancies and unsold development.

\section{Methodology}

This study involves primary and secondary research methods. A survey garnered primary data. The survey instrument was a questionnaire designed to allow respondents to give answers which could be ranked on the Likert scale, and enable analysis and interpretation using the Relative Importance Index method. The questions were generated from market-relevant issues and other topics which realtors and the general public raised regarding Abuja's high-end prices in relation to those of Lagos. The survey sample consisted of firms of estate surveyors and valuers who, by professional training and function, are reasonably expected to have in-depth knowledge and experience in these markets. The sample size was determined from the 2017 membership directory of the Nigerian Institution of Estate Surveyors and Valuers which respectively listed 367 and 130 registered firms in Lagos and Abuja. Of these numbers, respectively $184(50 \%)$ and $65(50 \%)$ were selected, making a total sample size of 249 on which the survey instrument was administered. The total number of responses received was 158 (representing $63 \%$ of the sample), 
and these were all found to be valid. The responses were analysed using the descriptive tool of Relative Importance Index (RII).

\subsection{The Study Areas}

Two sets of upscale residential districts, each in Abuja and Lagos, were considered to be comparable due to their relative prestige and exclusivity. These districts represent the study area. For Abuja, the districts are Asokoro and Maitama, while for Lagos, Lekki Peninsula (Phase 1) and Oniru were chosen.

Located to the north of the city, Asokoro and Maitama were created in the original master plan of the Federal Capital Territory and designed to be the best residential districts and the abodes of senior government officials. Asokoro harbours the "three arms zone" (the Presidency, the National Assembly and the Judiciary) while Maitama lies next to Asokoro.

Lekki is a naturally formed peninsula which fronts onto the Lekki and Lagos Lagoons. The Lekki (Phase 1) residential estate originated in the 1990s under the Lagos State Government's Housing Development Policy. From inception, it acquired a reputation as the best residential estate in Lagos. Lekki (Phase 1) is an extension to Victoria Island, which in the 1990s had started to lose its purely residential character to commerce as firms and businesses relocated from the deteriorating and neglected Lagos Island. The land area of Lekki (Phase 1) estate (Admiralty or left side) is 100 hectares while the entire peninsula is $755 \mathrm{~km}^{2}$ ( Lagos State Development Plan, 2013; Lekki Directory, 2016). The Oniru estate which is contiguous with Lekki (Phase 1) is much smaller in area at 732 acres (Jiboye, 2012).

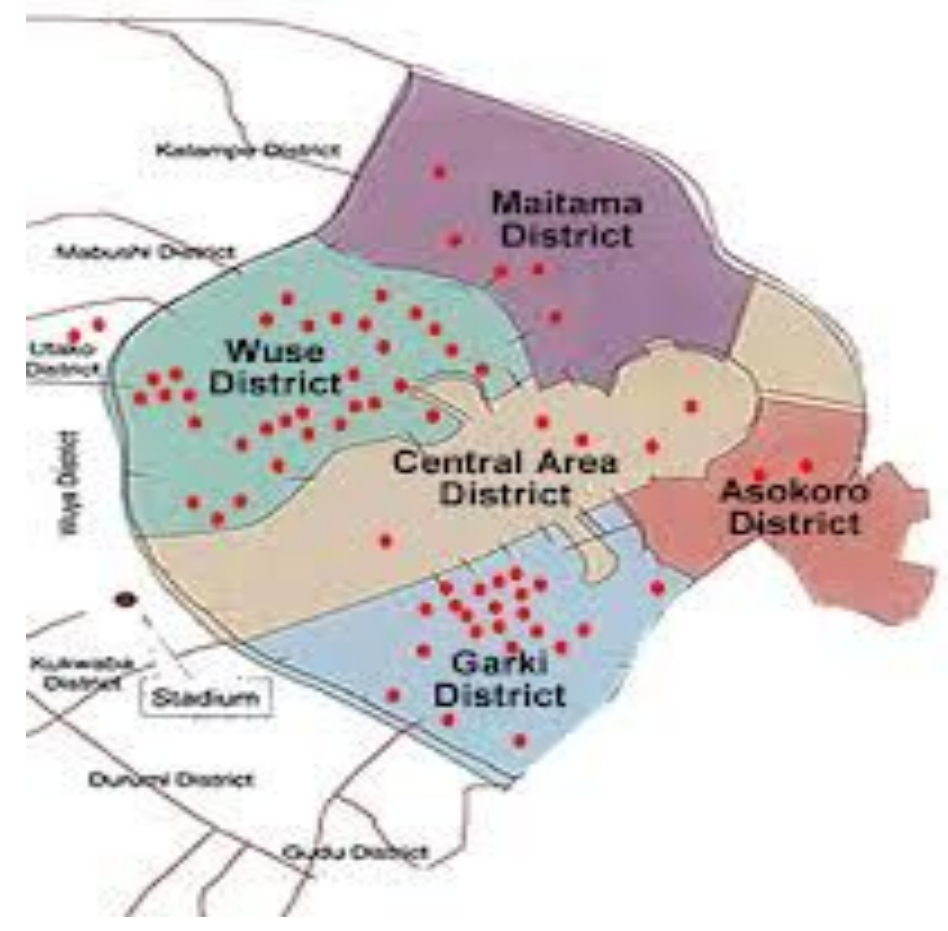

Figure 1: Maitama and Asokoro on Map of Abuja Districts (Phase 1) Source: Ministry of the Federal Capital Territory 


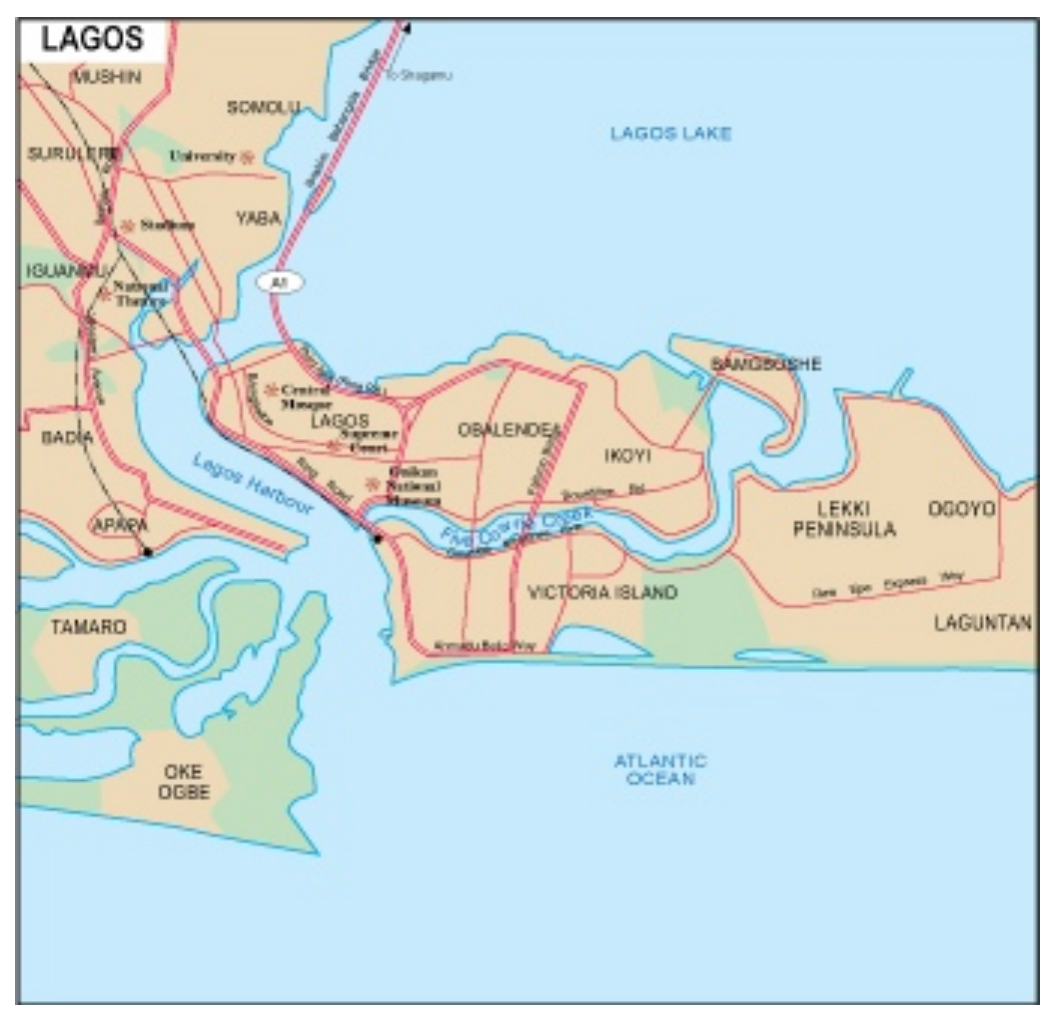

Figure 2: Map Showing Lekki Peninsula

Source: Google Earth

This study is restricted to these high-end residential properties which are defined as detached or semi-detached storey buildings with outhouses and other attachments such as basements, swimming pools and guest chalets, built in a modern constructional style with high-quality materials and finishes. They are located in areas exclusively zoned for low-density residential development. This definition also includes undeveloped residential land within such areas.

\section{Results}

Table 1 is a compilation of the broad range of asking prices in the years of the study. The figures show that from 2011 to 2015, asking prices for highend residential land and buildings in Abuja were consistently far higher than for the Lagos. Table 2 shows that over the study period, in terms of land prices, Abuja exceeded Lagos by between $45 \%$ and $129 \%$; the former also exceeded that latter by between $80 \%$ and $166 \%$ in regard to house prices, and in the case of rents by $150 \%$. 
Table 1: Range of Asking Prices (Development Land \&Houses) and Rents

\begin{tabular}{|c|c|c|c|c|c|}
\hline \multirow[t]{2}{*}{ Location } & \multirow[t]{3}{*}{ Year } & \multicolumn{2}{|c|}{ Abuja (N' millions) } & \multicolumn{2}{|c|}{ Lagos (N' millions) } \\
\hline & & Asokoro & Maitama & $\begin{array}{l}\text { Lekki (Phase } \\
\text { 1) }\end{array}$ & Oniru \\
\hline \multirow{5}{*}{$\begin{array}{l}\text { Land } \\
\text { (approx. 1000m2 } \\
\text { plot size) }\end{array}$} & & & $1000 m^{2}$ plot size & & \\
\hline & 2011 & $120-140$ & $120-170$ & $80-90$ & $100-110$ \\
\hline & 2012 & $\begin{array}{l}125-140 \\
125-150\end{array}$ & $\begin{array}{l}120-170 \\
125-180\end{array}$ & $\begin{array}{l}80-90 \\
90-100\end{array}$ & $\begin{array}{l}100-110 \\
110-120\end{array}$ \\
\hline & 2014 & $140-220$ & $200-250$ & $100-120$ & $100-120$ \\
\hline & 2015 & $180-300$ & $250-300$ & $100-120$ & $100-120$ \\
\hline \multicolumn{6}{|c|}{$* 500 m^{2}$ plot size } \\
\hline \multirow{5}{*}{$\begin{array}{l}\text { Houses } \\
\text { (5 bedroom) }\end{array}$} & 2011 & $150-180$ & $180-280$ & $100-120$ & $100-120$ \\
\hline & 2012 & $150-180$ & $220-280$ & $100-120$ & $100-120$ \\
\hline & 2013 & $150-200$ & $200-600$ & $100-120$ & $100-130$ \\
\hline & 2014 & $135-200$ & $200-600$ & $100-120$ & $100-130$ \\
\hline & 2015 & $135-200$ & $250-800$ & $125-135$ & $125-135$ \\
\hline $\begin{array}{l}\text { Annual } \\
\text { Rents }\end{array}$ & $\begin{array}{ll}2011- \\
2015\end{array}$ & $\begin{array}{l}\text { Between } \\
\text { million }\end{array}$ & million and 35 & \multicolumn{2}{|c|}{$\begin{array}{l}\text { Between } \$ 5 \text { million and } \$ 15 \\
\text { million }\end{array}$} \\
\hline
\end{tabular}

Source: Castles weekly publications (2011-2015) * The approx. $1000 m^{2}$ plots are usually split into two and developed into separate structures

Table 2: Average Prices and Rents

Price \&Rent (N'millions)

\begin{tabular}{|c|c|c|c|c|c|c|c|c|c|c|}
\hline & \multicolumn{5}{|c|}{$\begin{array}{c}\text { Abuja } \\
\text { Asokoro \& Maitama Averages }(\%)\end{array}$} & \multicolumn{5}{|c|}{$\begin{array}{c}\text { Lagos } \\
\text { Lekki (Phase 1) \& Oniru } \\
\text { Averages }(\%)\end{array}$} \\
\hline & 2011 & 2012 & 2013 & 2014 & 2015 & 2011 & 2012 & 2013 & 2014 & 2015 \\
\hline $\begin{array}{l}\text { Land } \\
\text { Increase: }\end{array}$ & 275 & $\begin{array}{l}277.5 \\
2.5\end{array}$ & $\begin{array}{l}442.5 \\
165.00\end{array}$ & $\begin{array}{l}405 \\
-37.5\end{array}$ & $\begin{array}{l}515 \\
110\end{array}$ & 190 & $\begin{array}{c}190 \\
-\end{array}$ & $\begin{array}{l}205 \\
15\end{array}$ & $\begin{array}{l}225 \\
20\end{array}$ & $\begin{array}{l}225 \\
-\end{array}$ \\
\hline $\begin{array}{l}\text { Houses } \\
\text { Increase: }\end{array}$ & 395 & $\begin{array}{l}415 \\
20\end{array}$ & $\begin{array}{l}575 \\
160\end{array}$ & $\begin{array}{l}567.5 \\
-7.5\end{array}$ & $\begin{array}{l}692.5 \\
125\end{array}$ & 220 & $\begin{array}{c}220 \\
-\end{array}$ & $\begin{array}{l}225 \\
5.0\end{array}$ & $\begin{array}{c}225 \\
-\end{array}$ & $\begin{array}{l}260 \\
35\end{array}$ \\
\hline $\begin{array}{l}\text { Rents } \\
\% \\
\text { difference }\end{array}$ & \multicolumn{5}{|c|}{$\begin{array}{c}\forall 25 \text { milli } \\
150\end{array}$} & \multicolumn{5}{|c|}{$\begin{array}{l}\$ 10 \text { million } \\
\text { - }\end{array}$} \\
\hline
\end{tabular}

Table 3, below, displays the extent of agreement of the respondents on the issues relating to the local economies and markets, comparable high-end residential property prices, comparative land supply and accessibility, pronounced vacancies and investors' predisposition towards professional advice including pre-investment studies.

The questionnaires were administered to firms of estate surveying and valuation, not individual estate surveyors and valuers. This was done in order to improve the chances of receiving responses which would be broadly representative of market experience. It was decided that this method would create a better picture of the issues arising in the two study areas under 
comparison. The responses of the firms are the summations of their market experiences. There were thirty questions on which responses were sought. This number of questions allowed adequate coverage of the issues from both the Abuja and Lagos perspective. The analysis of the responses was done using the RII method to ascertain the degree of importance attached to each statement by the respondents. The method allows the respondent to weight their responses according to the extent of their agreement with each statement or issue. This method was adopted because the thirty issues in the questionnaire are all potential explanatory factors in the study. It was decided that having each factor weighted by each respondent should give a guide as to their relative importance, thereby enabling inferences to be drawn. The formula for the RII is as follows:

Where:

$$
\text { Relative Importance Index }=\frac{\Sigma_{w}}{A N}=\frac{5 n_{5}+4 n_{4}+3 n_{3}+2 n_{2}+1 n_{1}}{5 N}
$$

In the above equation, $\mathrm{w}$ is the weighting given to each factor by the respondent, ranging from 1 to 5 . For example, $n_{1}=$ number of respondents for Strongly Disagree, $\mathrm{n}_{2}=$ number of respondents for Disagree, $\mathrm{n}_{3}=$ number of respondents for Undecided, $n_{4}=$ number of respondents for Agree and $n_{5}=$ number of respondents for Strongly Agree. The highest weight in the study is A (i.e. 5) while $\mathrm{N}$ is the total number of respondents. The relative importance index ranges from 0 to 1 (Tam \& Le, 2006).

In effect, the RII is a mean score for an item, and it is scaled to produce a value between 1/A and 1; where $\mathrm{A}$ is the number of response categories in the survey. Out of the thirty factors in the survey for all of which indices were computed and ranked, a selection of the most relevant has been made and can be found displayed in Table 3. They are in two categories: those with the highest indices (i.e. the strongest points of agreement by respondents) and those with the lowest indices (i.e. the strongest points of disagreement) by respondents. The RII sorts out the factors from the "most" to the "least". Each of the two categories has ten factors. To the left of Table 3 are the "most" and to its right are the "least". 
Table 3: Field Survey of Estate Surveying and Valuation Firms in Abuja \& Lagos

\section{S/N Strongest Agreements (Highest rankings) Land and house prices in Abuja were \\ 1. generally higher than for Lagos \\ 2. Asokoro and Maitama land and house prices were highest of all Abuja districts between 2011 and 2015}

3. Abuja was associated more than Lagos with the phenomenon of vacancy in 2011-2015

4. Lack of professional advice on development and letting contributed to unlet property in Abuja

5. Residential development land in Lagos is always available from outside government sources

6. Property being left unoccupied for years has been associated more with Abuja than Lagos

7. Land cost is a major cause of high development costs in Abuja in 20112015

8. The Lagos real estate market was more resilient than Abuja's between 2011 \& 2015

9. Abuja investors appear unworried about property being unsold/unlet for years

10. Low demand was contributory to unlet property in Abuja in the period 20112015
RII
Strongest Disagreements (Lowest rankings)
There was justification for the high
0.964 Abuja asking prices/rents
Bottlenecks and bureaucracy in land acquisition \& documentation are greater in Lagos than in Abuja
Abuja residential investments are 0.950 more secure than Lagos'

0.389

Pre-investment studies are carried out on the development projects in Abuja residential development projects

It is easier to acquire/buy land in the

0.927 Abuja property market than in Lagos'

Your clients agree that askingprices of "for sale" property should 0.915 be professionally determined beforehand

Higher asking prices for Abuja 0.850 houses than Lagos indicated a greater resilience

Abuja investors always seek an opinion of value before putting 0.834 property on the market for sale/letting purposes

Pre-investment studies are done for 0.733

Your clients agree that asking prices of "to let" property should be professionally determined 0.529 beforehand

The highest importance (0.964) was given to the statement that land and house prices in Abuja were higher than in Lagos. The analyses of the asking prices corroborate this. The variable with the lowest scoring factor $(0.389)$ was that the respondents do not agree that the high Abuja prices were justified. The other factors of investigation fall in-between these two limits. Putting together the highest and lowest scoring factors, one can conclude that the Abuja prices which were higher than Lagos between 2011 and 2015 were 
not justified in the judgement of the respondents. Other factors with a high level of agreement are in respect of comparative vacancies, land availability, investor expectations and professional advice. The details of the factors are treated in the discussion section.

The findings can be separated into two categories. The first relates to asking prices and the second to the survey. In the first category, the findings suggest that:

(1) Asking prices for land and houses as well as rents in Abuja exceed those of Lagos throughout all the years of the study.

(2) The market knowledge and perceptions of the respondents indicate that there are differences between the study areas. These differences are in the respective strengths of their local markets, comparative land availability and vacancies while there is a similarity in the predisposition of most clients not to use professional advisers on letting, sale and development issues.

\section{Discussion of Findings}

The discussion explains the findings and whether the Abuja prices are realistic, what relationship they may have with value as well as the significance of the pronounced vacancy phenomenon on the value concept and for the real estate industry.

\subsection{Comparative Status of the Local Economies and Markets}

The respondents ascribe a greater resilience (0.834) to Lagos' real estate market. By indices of 0.812 and 0.735 respectively, they agree that low demand for what was produced in Abuja contributed to unlet and unsold property. This is not indicative of resilience. Since the strength of property markets lies in the local economy, it can be inferred that the Abuja economy (of which the study areas are a part) was less resilient than Lagos'. In the remainder of this subsection, the two local economies are compared.

Table 4: Economic Characteristics of the Study Areas

\begin{tabular}{|c|c|c|}
\hline & Lagos & Abuja \\
\hline Location & South-West & Centre \\
\hline Population & $\begin{array}{l}\text { 21,647,292 (2015) Nigeria's \& } \\
\text { Africa's largest metropolis }\end{array}$ & $\begin{array}{l}3,100,000(2015) \text { (Nigeria's } \\
4^{\text {th }} \text { largest metropolis) }\end{array}$ \\
\hline $\begin{array}{l}\text { Economic } \\
\text { Base }\end{array}$ & $\begin{array}{l}\text { Manufacturing, commerce, } \\
\text { business, services; harbours } \\
40 \% \text { of Nigeria's industrial } \\
\text { capacity; } 65 \% \text { of businesses }\end{array}$ & $\begin{array}{l}\text { Administration, Business, } \\
\text { Services }\end{array}$ \\
\hline $\begin{array}{l}\text { Economic } \\
\text { Output }\end{array}$ & GDP: \$131 billion (2015) & $\$ 8.7$ billion (2015) \\
\hline $\begin{array}{l}\text { Annual } \\
\text { Income } \\
\text { Capita }\end{array}$ & $\$ 4,333(2014)$ & $* \$ 2,682(2015)$ \\
\hline
\end{tabular}


Table 4 shows that Abuja's 2015 GDP and annual per capita income for Abuja's were both considerably lower than Lagos'. The ratio of Lagos' population to Abuja's and its diversified economy clearly show the enormous difference between the two. Their economic bases are also unmatched to the extent that Lagos' 2014 contribution to Nigeria's non-oil GDP was over 25\% (Akabueze, 2014). The relatively high per capita income of Abuja is partly attributable to the overhead cost of Nigeria's top-heavy federal government system under which the federal top-tier takes $52.68 \%$ of consolidated revenue receipts leaving to the second and third tiers respectively $26.72 \%$ and $20.69 \%$. Abuja's buoyancy has been more the result of aggregated public expenditure than of installed, productive activity. Nwosu (2016) alludes to the expenditure implication of top-heavy federalism in stating that considerable resources lie at the disposal of the federal tier of governmental, but that these are not prudently deployed to the execution of the many federal responsibilities, thereby leading to excessive waste.

The respondents (0.771) agree that government expenditure buoys up the Abuja economy. By implication, this also benefits the study areas where senior public officials reside. There are various levels of government in the Federal Capital Territory whose combined expenditures constitute a strong stimulus for economic activity. Present in the city are: The Federal Government (the Presidency, the Legislature and the Judiciary); The Federal Ministries, Departments and Agencies, The Ministry of the Federal Capital Territory; and The Abuja Municipal and Area Councils. Government expenditure is a significant factor in the level of aggregate demand.

On the other hand, Lagos is sustained by the existence of linkages, the creation of agglomeration economies and the multiplier effects of private sector investment and industry. Ambode (2017) attributes Lagos' advantage to its hosting of over $50 \%$ of Nigeria's commercial activities, comprising businesses, manufacturers, financial institutions as well as small and medium enterprises which, on the basis of GDP, would rank Lagos amongst the five most productive economies in Africa were it to be regarded as a sovereign state. Its internal revenue profile was $\$ 7$ billion (1999), $\$ 11$ billion (2008), over $\$ 15$ billion (2010) and $\$ 26$ billion (2017). It is expected to attain $\$ 50$ billion by 2020 (Filani, 2012). While the argument can be advanced that Abuja also features representation from these same large business concerns, and therefore, also benefits from their activities, given that the scope of these operations is usually greater in Lagos, and so their presence boosts government revenue.

\subsection{The Matter of Vacancies}

Matters surrounding vacancies had high response rates from the respondents. There is a high rate of agreement (0.95) on Abuja's Asokoro and Maitama being associated with vacancy more than Lagos. Respondents emphasised the lengthy vacancies $(0.915)$ and also the high visibility of unsold and unlet development (0.905) in Abuja. Additionally, there was a high degree of agreement that vacancy lengths for "to let" property in Lagos were shorter at less than one year (0.739) compared with Abuja's which were longer than one year in duration (0.826). A completed project for which there are no takers is unviable and loss-making. The pervasiveness and length of the Abuja 
vacancies suggest that they cannot be readily associated with the natural vacancy rate concept, but instead come across as an abnormality.

\subsection{The Matter of Prices}

Respondents overwhelmingly agree that Asokoro and Maitama prices were highest in Abuja (0.959) and were also higher than Lagos (0.964). Where pricing keeps developments unoccupied or unsold for as long as eight years. The situation might either be attributed to low demand, oversupply or inappropriate development. However, research by Oyetunji and Olowofeso (2016) on the Lagos residential market found that a fluctuation in macroeconomic variables can produce changes in the price of residential real estate. These authors recommend the recognition of these factors in the assessment of rental value by valuers. In the case of Abuja, research by RIRFHUD (2016) estimates the housing deficit at 600,000 units which, in turn, suggests a need. However, there appears to be an ineffective demand which is traceable to pricing. This situation confirms the conventional wisdom that it is possible to price an item out of the market. It also confirms that price and value differ.

Etteng (2015) ascribes the situation to an overvaluation of asking rents. By inference, if rents can be overvalued, the same can happen to asking prices for land and houses. As to the responsibility for the overvalued rents and prices, the answer can be inferred from respondents' unequivocal agreement that clients/investors do not usually seek an opinion of value before placing their property on the market. In other words, price is arbitrarily fixed despite reality. This, however, is common to both markets. It would appear, however, that it is less of a disadvantage in Lagos due to the size and diversity of its market.

\subsection{Land Supply and Accessibility}

Responses to the issue of land yielded high agreement (0.850) in respect of the role which high supply cost plays in the cost of development in Abuja. Respondents also believe (0.927) that land is easier to obtain in Lagos. As the most crucial input in property development, land cost significantly influences project viability. Between Lagos and Abuja, there are differences in this regard. In Abuja, where land is primarily available from one source, The Ministry of the Federal Capital Territory, access is fraught with bureaucratic procedure, delays and the taint of malpractice. Original land allottees tend to resell their allocations at a premium, thereby creating a lucrative secondary market. Benson Ezem as reported by Babalola (2017) states that allocations of land, such as in the case of Idu Industrial Estate, do not always go to those who need them, but tend to end up with people whose motive is to resell at a profit. Respondents disagree that land acquisition in Abuja is less of a problem than in Lagos (0.470) while strongly agreeing that land is always available from outside government sources in Lagos (0.927).

\subsection{Investment Advice}

The respondents highly agree (0.938) that the lack of professional advice on development and letting contributed to unlet properties in Abuja. They also strongly agree that investors overlook professional advice $(0.787)$ and pre- 
investment studies (0.778). These indices may be explained by the fact that many investors build with their own funds and normal mortgage facilities (long-term loans) are not commonly available or affordable. It is usually when development funds are to be borrowed that pre-investment studies become an unavoidable demand of lenders.

The perception that many investor-developers tend to operate without the benefit of professional advice of the estate surveyor and valuer is supported by findings on Lagos by Oloke et al. (2017). The authors suggest that "house prices in the residential property market are largely fixed and reserved by the sellers [who] do not consider many of the determinants of housing price" due to a "lack of adequate knowledge of the housing market and lack of trust in the competence of professional agents..." (Oloke et al., 2017: p.31). All said and done, asking prices should have a basis in market reality in order to be considered as having a relationship with value, because value is a factor of the market. This argument is espoused by Oloke et al. (2017: p.31) as they also recommend that: "sellers undertake the valuation of their property before putting it in the market for sale or to let".

\subsection{Price, Value or Cost?}

In sum, it appears that there were justifications for the doubt long expressed by the public and real estate practitioners about Abuja's 2011-2015 prices. As conjectured in the introduction section, the doubt was probably due to their magnitude; their inconsistency with the city's essentially administrative function; and the abnormal vacancy phenomenon.

In the introduction, it was also argued that if figures described as prices have no basis in the market, then they cannot be associated with value. Similarly, if they do not reflect value, then they give a false notion of the market and the industry. Given the main finding that Abuja's 2011-2015 prices were unjustified when compared with Lagos, the ineluctable inference is that these prices, not being market-derived, are difficult to associate with value and so cannot be regarded as truly reflective of market strength.

Also raised in the introduction, is the appropriateness of deploying the terms "price" and "value" to useful things which are not serving any use and which, therefore, contradict the logic of rational economic activity. Going by Blackledge's (2009: p.27) value postulation, since: "nobody is prepared and able to purchase or rent it at that price", it is of no use in deciding about value. If it is conceded that there is no point in deciding about value for these perennially vacant properties, there should be in deciding about cost. The economic concept of cost is best deployed in defining what these long-term vacant edifices constitute: cost to the investor, cost to society and cost to the economy. As has been observed by Onwuanyi et al. (2017: p.401): "Where property is in profitable and productive use, it helps to drive productivity, which in turn, translates into wealth. However, where land resources are inefficiently deployed as in failed, unproductive or sub-optimal property investments, there is a reducing impact on the economy as a whole". 


\section{Practical Implications}

Firstly, the highly visible, though officially unrecorded, level of vacant lettable and unsold built-for-sale property in Abuja suggests the existence of an abnormal situation. Policymakers should investigate this given the economic implications - two of which are an implied land resource misallocation by the creation of useful assets which do not deliver value because they are either not in use or are not available for use. Secondly, real estate investors who choose to act without the benefit of professional advice on development, letting and sales, inevitably expose themselves to a higher level of risk, particularly in the Abuja market.

\section{Conclusion}

This study aimed to resolve whether or not the 2011-2015 asking prices for Abuja real estate were unusually high relative to Lagos'. Furthermore, it aimed to assess if the price trend was indicative of buoyancy given the high levels of unsold and unlet development during the same period. The conclusion suggests that Abuja's 2011-2015 prices were unusually high. Furthermore, they were not indicative of buoyancy and that Abuja's perennially vacant "to let" and "for sale" property, whose prices were not market-derived, are difficult to associate with value and therefore cannot be regarded as truly reflective of market strength. Because the vacancies are unusual and long-lasting, they are considered to be a disadvantage.

The findings are that Abuja prices were consistently higher than Lagos' and that this trend was not only unjustified in terms of comparative economic performance but also, anomalous being accompanied by high vacancies and unsold development lasting for periods longer than one year. There are also characteristic differences between the two locations in terms of land supply, land accessibility and vacancy levels which confirms that real estate markets tend to differ according to local conditions.

These findings offer a better understanding of Nigeria's two leading real estate markets, both for investors (prospective and existing) as well as policymakers. For the former, it disabuses the common notion that the prices which they arbitrarily fix for their properties are tantamount to value. Furthermore, it advises that successful real estate investing is associated more with professional investment advice than with the apparent reliance on "gut feeling". In the case of the latter, attention is drawn to the potentialities of real estate for economic development. Furthermore, emphasis is placed on the need to support the real estate industry through legislative reform of land administration and other measures of enablement and enhancement for improved performance. It is believed that these aspects will make for better decision-making at both policy-making and investing levels.

The insights offered by the study are as follows. Firstly, the impression of buoyancy conveyed by the Abuja market was more apparent than real, meaning that it was not more resilient than Lagos. Secondly, the abnormal 2011-2015 situation of the Abuja market is attributable to its peculiar characteristics. Thirdly, an examination of the Abuja situation using the economic principles of price and value suggest that its 2011-2015 prices, not 
being market-derived, are difficult to associate with value. Fourthly, Abuja's perpetually vacant "to let' and "for sale" developments (produced goods which are not being productive) are available but not affordable and thus signify cost more than value. Fifth, this research offers insights from the leading real estate markets of Nigeria. Lastly, this is a pioneering comparative study of Nigeria's most prominent real estate markets as well as of the pronounced Abuja vacancy phenomenon.

The study recommends that Nigeria's real estate investors need to acquire more knowledge of the real estate market just as stock investors must understand stock markets. Furthermore, there is a necessity for Nigeria's real estate investors to be appropriately guided by professional advisers just as stockbrokers guide stock investors. This is especially so given that the risks of real estate investment are accentuated by the immobility of the product. As such, investments which are based on unrealistic expectations may never be redeemed. These two steps will help to reduce investment risks. In addition, it is essential for these markets to develop a system for the collection, storage and retrieval of data. Finally, access to land in Abuja for private development needs improvement through a more transparent process which should come with a review of the land tenure law.

\section{References}

Abidoye, R. B. \& Chan, A.P.C. (2016). Critical Determinants of Residential Property Value: Professionals' Perspective. Journal of Facilities Management, 14(3), pp.283-300.

Abonta, R. (2015). Rising Cost of Rents Drive Abuja Residents Out Of FCT, Economic Confidential, $13^{\text {th }}$ January. Available at: www.economicconfidential.com (Accessed $3^{\text {rd }}$ January 2018).

Adejokun, S. \& Yunusa, A. (2015). Rising Cost of Rents Drive Abuja Residents Out of FCT, Economic Confidential, $6^{\text {th }}$ January. [Online]. Available at: www.economicconfidential.com (Accessed $3^{\text {rd }}$ January 2018).

Adeyemi, S. (2015). Rising Cost of Rents Drive Abuja Residents Out of FCT. Economic Confidential. 13 $3^{\text {th } J a n u a r y . ~ A v a i l a b l e ~ a t: ~}$ wwweconomicconfidential.com (Accessed 3 January 2018)

Akabueze, B.I. (2014). Lagos Contributes a Quarter of Nigeria's GDPCommissioner, ChannelsTV. [Online]. Available at: www.channelstv.com (Accessed 19 ${ }^{\text {th }}$ July 2017).

Akande, N. (2017). LCCI Wants National Assembly to Pass Real Estate Bills. PMNews, 21 April 2017. [Online]. Available at: www.pmnewsnigeria.com (Accessed $23^{\text {rd }}$ January 2018).

Alaba, O.T. \& Adegoke, O.J. (2015). Effect of the Interest Rate on Housing Price in Lagos Metropolis. American Journal of Business and Economic Management, 3(6), pp.384-394.

Ambode, A. (2017). Lagos GDP Hits \$131 Billion, News of Nigeria, 3 July. Available at: www.newsofnigeria.com. (Accessed 25 June 2018).

Babalola, J. (2017). Why Businesses are Leaving Abuja, The Nation, 29 November. [Online]. Available at: www.thenationonline.ng.com (Accessed 17 th $^{\text {January 2018). }}$ 
Brems, H. (1991). The Microeconomics of the Price Mechanism, Faculty Working Paper No.91-0163, College of Commerce and Business Administration, University of Illinois at Urbana-Champaign.

Blackledge, M. (2009). Introducing Property Valuation. New York: Routledge.

Castlesweekly. (2017). An Introduction to Abuja's High-end Locations, 1-7 October. 38, pp.9-10.

Federal Republic of Nigeria. (2017). Economic Recovery and Growth Plan 2017-2020, Federal Ministry of Budget and National Planning, February 2017.

Darlow, C. (1982). Valuation and Development Appraisal, The Estates Gazette Limited, London

Economistview (2005). The natural vacancy rate for housing, November 29,2005. [Online]. Available at: https://economistsview.typepad.com/economistsview/2005/11 (Accessed 17 $7^{\text {th }}$ May 2018).

Estateintel (2017). Nigerian Real Estate, Economic and Demographic Data. Estate Intel. [online]. Available at: https://estateintel.com/nigerianreal-estate-economic-demographic-data/RICS (Accessed $17^{\text {th }}$ January 2018).

Etteng E.I. (2015). Why Abuja Rentals are Overvalued, Vanguard, $11^{\text {th }}$ August, pp.27.

Filani, M.O. (2012). A City in Transition: Vision, Reform and Growth in Lagos, Nigeria. Available at: www.citiesalliance.com (Accessed 12 $2^{\text {th }}$ April 2017).

Fraser, W.D. (1984). Principles of Property Investment and Pricing. London: Macmillan Publishers Limited.

Harvey, J. (1996). The Economics of Real Property. London: Macmillan Publishers Limited.

Iroham, C.O., Durodola, O.D., Ayedun, C.A. \& Ogunbola, M.F. (2014). Comparative Study of Rental Values of Two Gated Estates in Lekki Peninsula, Lagos. Journal of Sustainable Development Studies, 5(2), pp.218-235.

Jiboye, A.D. (2012). Post-occupancy Evaluation of Residential Satisfaction in Lagos, Nigeria: Feedback for Residential Improvement. Frontiers of Architectural Research,1, pp.236-243.

Kingmakers. (2016). State of the States Rankings. [Online]. Available at: http://stateofstates.kingmakers.com.ng (Accessed 12 $12^{\text {th }}$ February 2018).

Kolawole, Y. (2015). Rising Rent, Vacant Houses and Homeless Tenants, Vanguard, 23 March. Available at: www.vanguardngr.com/2015(Accessed 17 August 2018).

Lagos State Bureau of Statistics. (2015). Lagos State Bureau of Statistics Home. [Online]. Available at: www.lagosstate.gov.ng (Accessed $17^{\text {th }}$ July 2017).

Lagos State Development Plan (2013). Lagos State Development Plan 20122025. [Online]. Available at: http://www.scribd.com (Accessed 17 April 2018).

Le, K.N. \&Tam, V.W.Y.(2007).A survey on effective assessment methods to enhance student learning, Australasian Journal of Engineering Education, 13(2), pp 13-20. 
LekkiDirectory.com. (2016). Lekki Master Plan. [Online]. Available at: www.lekkidirectory.com/lekki-master-plan (Accessed 12 ${ }^{\text {th }}$ May 2018).

Mabogunje, A.L. (2009). Land Reform in Nigeria: Progress, Problems and Prospects. Chairman Presidential Technical Committee for Land Reform. [Online]. Available at: www.siteresources.worldank.org (Accessed $11^{\text {th }}$ December 2017).

Minguzzi, G. (2014). The Role of Real Estate in the Economy, British Property Federation, 17 July. [Online]. Available at: www.pf.org.uk (Accessed 13 ${ }^{\text {th }}$ April 2018).

Nam, J., Han, J. \& Lee, C. (2016). Factors contributing to residential vacancies and some approaches to management in Gyeonggi Province, Korea. Sustainability, 8(4), pp.367-389.

National Bureau of Statistics. (2016). National Bureau of Statistics. [Online]. Available at: www.nigerianstat.gov.ng (Accessed 11 $11^{\text {th }}$ December 2017).

Nigeria Institution of Estate Surveyors and Valuers. (2017). Firms Directory. Available at: http://firms.niesv.org.ng/niesva-zfirms.php (Accessed $19^{\text {th }}$ April 2018).

Nwosu, A.B.C. (2016). Why the North Is Afraid of Restructuring, The Sun, September $15 . \quad$ [Online]. Available at: www.sunnewsonline.com/home/politics (Accessed 16 $6^{\text {th }}$ May 2018).

Odubola, I.O. \& Adeyemi, W. (2017). Effect of Socioeconomic Factors on the Rental Values of Accommodation in Lagos Metropolis. Equatorial Journal of Social Sciences and Human Behaviour, 2(3), pp.106-120.

Olajide, S.E., Lizam, M. \& Olajide, E.B. (2016). Understanding the Conceptual Definitions of Cost, Price, Worth and Value. IOSR Journal of Humanities and Social Sciences, 21(9), pp.53-57.

Oloke, O.C., Olawale, Y.A. \& Oni, A.S. (2017). Price Determination for Residential Properties in Lagos State, Nigeria: The Principal-agent Dilemma. International Journal of Economy, Management and Social Sciences, 6(6), pp.28-32.

Onwuanyi, N., Oyetunji, A. K. \& Chima, P. E. (2017). Role of the Estate Surveyor and Valuer's Professional Advice in the Urban Property Development Process, In Emerging Issues in Urban Land Use, Management and Development in Nigeria, M. B. Nuhu, M.T.A. Ajayi, I.A. Olatunji \& N. B. Udoekanem (Eds.), University of Abuja Press, pp.399-417.

Oyetunji, A.K. \& Olowofeso, E. (2016). Assessing the Impact of Selected Macroeconomic Variables in the Determinants of Sustainable Residential Housing Prices in Lagos. Ethiopian Journal of Environmental Sciences and Management, 9(4), pp.405-411.

PriceWaterhouseCoopers (PwC). (2015). Nigeria's Real Estate Market Outgrows GDP at 8.7\%, PriceWaterhouseCoopers, 1 June. [Online]. Available at: www.housingnews.com (Accessed $23^{\text {rd }}$ February 2018).

Real Foundation for Housing and Urban Development. (2017). State of the Abuja Housing Market Report. Available at: www.rirfhud.com (Accessed 14 ${ }^{\text {th }}$ June 2018).

Wahab, M.B., Morenikeji, G.B., Abdulkareem, S.O., Mammah, M. \& Adeogun, A.S. (2017). Effect of Macroeconomic Factors on 
Journal of African Real Estate Research Volume 3(2) 2018

Residential Property Returns in Abuja, Nigeria. EUL Journal of Social Sciences, 3(2): pp.133-149.

World Bank. (1989). World Bank Development Report. Oxford University Press: New York.

World Bank. (2014). Doing Business-ease of Doing Business in FCT (Abuja)-Nigeria. [Online]. Available at: www.doingbusiness.org (Accessed 15 ${ }^{\text {th }}$ March 2018).

World Bank. (2017). Nigeria Overview. [Online]. Available at: www.worldbankgroup.org (Accessed $15^{\text {th }}$ February 2018). 